\title{
Nutritional ingredient by-product of the pistachio oil industry: physicochemical characterization
}

\author{
María V. Salinas $^{1}\left(\mathbb{D} \cdot\right.$ Luciano M. Guardianelli $^{1} \cdot$ Leonardo P. Sciammaro $^{1}$ • \\ Gianluca Picariello ${ }^{2}$ Gianfrano Mamone $^{2}$ - María C. Puppo ${ }^{1,3}$
}

Revised: 24 May 2020/Accepted: 19 June 2020/Published online: 29 June 2020

(C) Association of Food Scientists \& Technologists (India) 2020

\begin{abstract}
Pistachio flour obtained from oil industry was nutritionally characterized for use as food ingredient in functional foods. Proximal composition, jointly with mineral content, amino acids and fatty acid profile were studied. In addition, different components present in this food ingredient have been analyzed by attenuated total reflectance Fourier transform infrared spectroscopy and thermal properties of proteins were evaluated by differential scanning calorimetry. This flour presented high mineral content such as potassium, phosphorus, magnesium and calcium. Moreover, high amount of unsaturated fatty acids, mainly oleic and linoleic were found. Secondary structure of proteins mainly was formed by parallel $\beta$-sheet and $\alpha$-helix. In the by-product, pistachio protein is in a native state and is able to be denatured at temperatures higher than $100{ }^{\circ} \mathrm{C}$. Therefore, food processing of this ingredient can affect the structure of components.
\end{abstract}

Keywords Pistacia vera cv Kerman - Amino acid composition · Fatty acid profile - Minerals - Denaturation protein · Protein structure

María V. Salinas

salinasvicky@hotmail.com

1 CIDCA (CIC-CONICET, Facultad de Ciencias Exactas, Universidad Nacional de La Plata), 47 y 116, 1900, La Plata, Argentina

2 Istituto Di Scienze Dell'Alimentazione, Consiglio Nazionale Delle Ricerche (CNR), Via Roma 64, 83100 Avellino, Italy

3 Facultad de Ciencias Agrarias y Forestales, Universidad Nacional de La Plata, 60 y 119, 1900, La Plata, Argentina

\section{Introduction}

Pistachio seeds derived from a tree of the Mediterranean countries, adaptable to arid areas belonging to the Pistacea genus, family of the Anacardaceae. Iran is the country with largest producers and exporters of pistachio in the world (Ehsanpour et al. 2010). Argentina has an extensive territory with diversity of climates, being Mendoza and San Juan ideal areas for the cultivation of pistachio. Pistachio raw nut contain $45.32 \%$ of lipids with $53 \%$ of total monounsaturated fatty acid, $33 \%$ of polyunsaturated and $13 \%$ of total saturated fatty acids (USDA 2018). Also, minerals with major proportions of calcium, magnesium, zinc, iron, phosphorus and potassium were reported. In addition, pistachio nut has $10.6 \%$ of total dietary fiber, $27.17 \%$ of availability carbohydrates, and $20.16 \%$ of protein.

A nutritional important aspect of the lipid fraction is the knowledge of the fatty acid profile. Essential fatty acids are

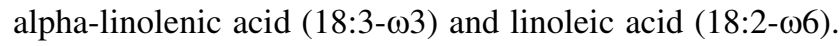
Some other fatty acids are sometimes classified as "conditionally essential", meaning that they can become essential under some developmental or disease conditions. Examples include docosahexaenoic acid (22:6- 03$)$ and gamma-linolenic acid (18:3- $\omega 6)$ (Joint FAO 2010). Another important component from the nutritional and functional point of view is the protein. The essential amino acids of proteins have carbon skeletons that cannot be synthesized by humans, and therefore they must be provided through the diet; they are important for the growth and maintenance of metabolic requirements. Other category is "conditionally essentials" amino acids, are those that are not normally required in the diet but under specific physiological or pathological conditions the human body cannot synthesize them in adequate amounts, and in this 
context their intake becomes therefore indispensable (Joint WHO 2007).

Fourier transform infrared spectroscopy (FTIR) has become a powerful analytical tool in food analysis for monitoring changes in structure of different molecules when they were subjected to different processes. It was used for evaluating the oxidation degree of edible oils (Guillén and Cabo 1999), for characterization or classification different almond cultivars (García et al. 2013); and also for studying secondary structure of proteins in biological systems (Gerbino et al. 2011). In addition, this technique is valuable in evaluating changes in protein structure due to folding or unfolding processes (Barth 2007).

On the other hand, thermal techniques have also been employed for food analysis. Differential scanning calorimetry (DSC) is a very useful technique for studying the thermal properties of polymers, especially denaturation of proteins (Konieczny et al. 2016) and starch gelatinization (Tananuwong and Reid 2005). However, no previous studies in thermal properties of pistachio were found.

Different authors have studied the fatty acid, carbohydrate and amino acid composition on dried pistachio or $\gamma$ irradiated nuts (Clarke et al. 1976; Gecgel et al. 2011). Shokraii and Esen (1988) also studied the composition, solubility and patterns of proteins isolated from Kerman pistachio nut. These authors found that $66 \%$ of total proteins are globulin while albumin, glutelin, and prolamins contributed in a minor proportion with 25,7 and $2 \%$, respectively.

Although there are studies on pistachio nut composition (Clarke et al. 1976), the characterization of the flour obtained as by-product of the oil industry for consumption as ingredient for human foods, has not been studied at the present. Pardo-Giménez et al. (2016) used the defatted pistachio meal to evaluate the agronomic performance as a compost supplement for button mushroom crops and to supplement the Pleurotus mushroom substrate.

The consumption of pistachio in Argentina is low; nevertheless a sustained growth in the production of delicate gourmet edible oils has been taking place in recent years being an economic activity of great relevance at present. In this sense, the elaboration of non-traditional vegetable oils, such as that obtained from pistachio (Pistacia vera L. genotype Kerman) offers an unexplored opportunity for new foods for haute-cuisine. This increase in the production of this kind of oils generates a remnant by-product that could be used in the form of flour, as a potential ingredient for human consumption. Thus, the objective of this work was to evaluate the chemical composition and nutritional quality of pistachio flour obtained as by-product of the Argentinian pistachio oil manufacture, in order to use it as an ingredient for food industry.

\section{Materials and methods}

\section{Materials}

Pistachio flour obtained as by-product of oil industry (Aceites del Desierto S.R.L., Argentina) included under vacuum in individual bags $(1 \mathrm{~kg})$, was provided by the factory and stored at $4{ }^{\circ} \mathrm{C}$ until their use. The oil extraction process was performed by hydraulic press at room temperature.

\section{Methods}

\section{Proximal composition of pistachio flour}

Moisture content of pistachio flour was determined by drying in an vacuum oven $\left(5 \mathrm{~h}\right.$ at $\left.70 \pm 1{ }^{\circ} \mathrm{C}, 13.3 \mathrm{kPa}\right)$. Content of ash was determined at $550{ }^{\circ} \mathrm{C}$ by direct method, contents of protein and lipids by Kjeldhal and Soxhlet methods, respectively (AACC 2000). Total dietary fiber was determined according to method 32-05.01 (AACC 2000) using the Megazyme kit (Megazyme Int. Ireland Ltd., Wicklow, Ireland).

Available carbohydrates. Glucose, fructose, sucrose and starch were determined through High Performance Liquid Chromatography (HPLC). In a first assay, soluble sugars were extracted with Mili-Q water from defatted flour according to Eliasson (2006). Large soluble molecules such as polysaccharides and proteins can be removed by coprecipitation with Carrez I and Carrez II. This mixture was heated $\left(70{ }^{\circ} \mathrm{C}, 600 \mathrm{rpm}\right)$ for $30 \mathrm{~min}$ in a thermomixer (DLAB, Riverside, USA). Then, was brought to adequate final volume with acetonitrile and centrifuged for $10 \mathrm{~min}$ at $580 \mathrm{~g}$. In other experience, starch was determined measuring the amount of glucose that was obtained after total hydrolysis of starch with $\mathrm{HCl} 16.7 \% \mathrm{v} / \mathrm{v}$ solution at reflux during $2 \mathrm{~h}$. Solution was cooled at room temperature, neutralized to $\mathrm{pH} 8$ and brought to an adequate final volume with acetonitrile and then was centrifuged for $10 \mathrm{~min}$ at $580 \mathrm{~g}$.

Supernatants of both assays were filtered through a $0.45 \mu \mathrm{m}$ MSI filter before injecting them into the chromatograph Waters 1525 (Waters Corporation, Massachusetts, USA) using a refractive index detector Waters 2414 adequate for carbohydrates identification. The column used at $30{ }^{\circ} \mathrm{C}$ was a $\mathrm{C} 18$-amide (particle size: $3.5 \mu \mathrm{m}$, i.d: $4.5 \mathrm{~mm}$, length: $150 \mathrm{~mm}$ ) (Thermo Fisher Scientific Inc. Massachusetts, USA). Aliquots of $20 \mu \mathrm{L}$ were injected and eluted with isocratic aqueous acetonitrile (75:25 v/v) solution with $0.2 \%$ ethylenediamine at a flow rate of $1.0 \mathrm{~mL} / \mathrm{min}$. 
The sugars peak areas were measured and identified by comparison with the retention times of the standards solutions of glucose, fructose, and sucrose (Sigma-Aldrich, Missouri, USA) using a PeakFit software (version 4.12 for Windows, SPSS Inc., Chicago, IL, USA).

The linear range for the standard was: $0.05-12.9 \mathrm{mg} / \mathrm{mL}$ for fructose $\left(\mathrm{y}=33.329 \mathrm{x} ; \mathrm{r}^{2}=0.998\right), 0.05-13.6 \mathrm{mg} / \mathrm{mL}$ for glucose $\left(\mathrm{y}=33.526 \mathrm{x} ; \mathrm{r}^{2}=0.998\right)$, and $0.05-12.5 \mathrm{mg} /$ $\mathrm{mL}$ for sucrose $\left(\mathrm{y}=34.27 \mathrm{x} ; \mathrm{r}^{2}=0.998\right)$ in mobile phase. The sugars data were expressed as $\mathrm{g}$ per $100 \mathrm{~g}$ of by-product flour. Assays were performed by duplicate.

Water activity of pistachio flour was measured at $25{ }^{\circ} \mathrm{C}$ using an electronic dew-point water activity with Aqualab Series 4 TEV meter (Decagon Devices, Pullman, Washington, USA). Measurements were carried out in triplicate.

\section{Total phenolics content and antioxidant activity of pistachio flour}

Extraction process Pistachio flour $(\approx 0.7 \mathrm{~g})$ was extracted according to Carbas et al. (2019) with $10 \mathrm{~mL}$ of acetone during $15 \mathrm{~min}$ and then was centrifuged $15 \mathrm{~min}$ at $1030 \mathrm{~g}$. The residue was re-extracted with $10 \mathrm{~mL}$ of aqueous acetone $(70: 30 \mathrm{v} / \mathrm{v})$ until a clear solution was obtained. Supernatants were combined, shaken in a tube with chloroform (2:1 chloroform:acetone) and stored overnight at $4{ }^{\circ} \mathrm{C}$. Then, residual acetone of aqueous phases (top portion) was evaporated using Buchi rotavapor R 200 (Büchi Labortechnik AG, Postfach, CH-9230, Flawil, Switzerland) at $40{ }^{\circ} \mathrm{C}$. Finally, the extract was diluted to $25 \mathrm{~mL}$ with distilled water.

Total phenolics The total phenolic content was determined by Folin-Ciocalteu (FC) method according to Singleton et al. (1999): $50 \mu \mathrm{L}$ of extract ("Extraction process" section), $750 \mu \mathrm{L}$ of distilled water and $50 \mu \mathrm{L}$ of FC reagent were combined and mixed. After $3 \mathrm{~min}, 150 \mu \mathrm{L}$ of $1 \mathrm{~N}$ $\mathrm{Na}_{2} \mathrm{CO}_{3}$ solution was added. The solution was incubated in dark at $25{ }^{\circ} \mathrm{C}$ for $2 \mathrm{~h}$. The absorbance was measured at $760 \mathrm{~nm}$ using a spectrophotometer UVmini-1240 (Shimadzu, Tokio, Japan) and the results were expressed in milligram of gallic acid equivalents (GAE) per gram of flour. The linear range for GAE was between 0.00 and $0.250 \mathrm{mg} / \mathrm{mL}\left(\mathrm{y}=2.5764 \mathrm{x} ; \mathrm{r}^{2}=0.996\right)$.

Ferric ion reducing antioxidant power assay (FRAP) This assay was performed according to Carbas et al (2019). Pistachio flour extracts $(100 \mu \mathrm{L})$ were mixed with $900 \mu \mathrm{L}$ of the freshly FRAP reagent for $60 \mathrm{~min}$ in the dark condition. The absorbancewas measured at $593 \mathrm{~nm}$. The standard curve was linear between 0 and $99 \mu \mathrm{g} / \mathrm{mL}$ of 6-hydroxy-2,5,7,8-tetramethylchroman-2-carboxylic acid (Trolox). Results were expressed as microgram of Trolox per gram of pistachio flour ( $\mu \mathrm{g}$ Trolox/g). All determinations were performed in triplicate.

Free radical scavenger activity on 2,2-diphenyl-1-picrylhydrazyl (DPPH) To measure antioxidant capacity with $\mathrm{DPPH}^{\circ}$ radical, extracts were obtained as described above ("Extraction process" section). The $\mathrm{DPPH}^{\circ}$ assay was done according to the method described by Kedare and Singh (2011). Test tubes containing 0, 5, 10, 20, 30, 40, 80, 115 and $150 \mu \mathrm{L}$ of sample ("Extraction process" section) and ethanol to a final volume of $1000 \mu \mathrm{L}$ were prepared. After that, $1000 \mu \mathrm{L}$ of a $30 \mathrm{mg} / \mathrm{L}$ of the radical $\mathrm{DPPH}^{\circ}$ dissolved in ethanol solution was added. Samples were vortexed and incubated in darkness at $20{ }^{\circ} \mathrm{C}$ for $90 \mathrm{~min}$. The absorbance was measured at $515 \mathrm{~nm}$ in a spectrophotometer UVmini1240 (Shimadzu, Tokio, Japan). Result is expressed as $\mathrm{EC}_{50}$ (concentration required to obtain a $50 \%$ of antioxidant effect). All determinations were performed in triplicate.

\section{Nutritional characterization of pistachio flour}

Mineral content Pistachio flour $(0.5 \mathrm{~g})$ was digested with $10 \mathrm{~mL}$ of $85 \%$ high purity $\mathrm{HNO}_{3}$ using microwave technology (QLABPro, Questron Technology Corp., Mississauga, Canada). The digest was diluted to $50 \mathrm{~mL}$ with distilled water and filtered with syringe filters $(0.45 \mu \mathrm{m})$. Minerals, such as phosphorus, iron, calcium, sodium, zinc, manganese, molybdenum, selenium, magnesium, copper and potassium were analyzed by an inductively coupled plasma optical emission spectrometer, ICP-OES model ICPE-9820 (Shimadzu, Japan) equipped with an ASX-520 Automatic Autosampler (Cetac Technologies). Assays were performed in duplicate.

Fatty acid analysis Lipids fractions (2 g) were derivatized in glass tube using $4 \mathrm{~mL}$ of solution of concentrated $\mathrm{HCl}$ in methanol $(5 \% \mathrm{v} / \mathrm{v})$. The tubes were tightly capped, vigorously shaken and placed in boiling water for $10 \mathrm{~min}$. After cooling, $2 \mathrm{~mL}$ of mili-Q distilled water and $1 \mathrm{~mL}$ of hexane were added. After shaken, were centrifuged $(1600 g$, $15 \mathrm{~min}$ ) until both layers were clear. The upper phase with the methyl esters was filtered $(0.45 \mu \mathrm{m})$ and transferred to $5 \mathrm{~mL}$ glass vials, which were analyzed by using a gas chromatograph Agilent Technologies 7890A (Agilent Technologies; Santa Clara, CA, SA) equipped with Supelco capillary column DB $23(30 \mathrm{~m}, 250 \mu \mathrm{m}$ i.d., $0.25 \mathrm{~mm}$ ) and flame ionization detector (FID) according to Guardianelli et al. (2019). Analyses were conducted in split mode (50:1). The oven temperature program was: isotherm at $50{ }^{\circ} \mathrm{C}$ for $1 \mathrm{~min}, 50-175{ }^{\circ} \mathrm{C}$ at a rate of $25^{\circ} \mathrm{C} / \mathrm{min}$, $175-230{ }^{\circ} \mathrm{C}$ at a rate of $4{ }^{\circ} \mathrm{C} / \mathrm{min}$, isotherm at $230{ }^{\circ} \mathrm{C}$ for $15 \mathrm{~min}$. Helium was used as carrier gas (flow rate = 
$0.4763 \mathrm{~mL} / \mathrm{min}$ ). Injector and detector temperatures were held to 250 and $280{ }^{\circ} \mathrm{C}$, respectively. Fatty acids were identified by comparison with the retention times of standards fatty acids methyl ester Supelco 37-Component FAME Mix (Sigma-Aldrich, USA) and the area of different peaks were analyzed using the PeakFit software (version 4.12 for Windows, SPSS Inc., Chicago, IL, USA). Assays were performed by duplicate.

Amino acid analysis Pistachio flour was digested in glass vials with $6 \mathrm{M} \mathrm{HCl}$ ( $2 \mathrm{mg}$ protein/1.5 mL acid solution). The vials were sealed in anaerobic conditions using nitrogen gas and incubated in oven at $110{ }^{\circ} \mathrm{C}$ for $24 \mathrm{~h}$. Amino acids were derivatized with diethyl ethoxymethylenemalonate and determined by RP-HPLC according to a Cian et al. (2015). D,L- $\boldsymbol{\alpha}$-Aminobutyric acid as internal standard was used. An HPLC Agilent Serie 1100 with a detector of variable wavelength VW (Santa Clara, CA, USA) was utilized. A reverse phase column of $300 \times 3.9 \mathrm{~mm}$ internal diameter (Novapack C18, $4 \mathrm{~m}$; Waters) at $18{ }^{\circ} \mathrm{C}$ was used. Samples were eluted with a binary gradient solution at a flux rate of $0.9 \mathrm{~mL} / \mathrm{min}$.

Mobile phase consisted in the mix of two solvents: (A) sodium acetate $(25 \mathrm{mM})$ containing sodium azide $(0.02 \% \mathrm{w} / \mathrm{v}) \mathrm{pH} 6.0$, and $(\mathrm{B})$ acetonitrile. The following gradient condition used were: $0.0-3.0 \mathrm{~min}$ with a linear gradient from A:B (91:9) to A:B (86:14); 3.013.0 min with A:B (86:14); 13.0-30.0 min with the linear gradient A:B (86:14) to A:B (69:31). Then, continue with A:B (69:31) for $5 \mathrm{~min}$. Amino acids eluted were detected at $280 \mathrm{~nm}$. Tryptophan was determined by RP-HPLC after an alkaline hydrolysis according to the method described by Yust et al. (2004). Derivatized amino acids were identified and quantified by comparison with the retention times and areas ratios of standard amino acids mixture with the internal standard. Assays were performed in duplicate. Results were expressed in $\mathrm{mg}$ of amino acid per $100 \mathrm{~g}$ of protein.

\section{Structural and thermal properties of pistachio by-product}

Fourier-transform infrared spectroscopy (FTIR) FTIR spectra of pistachio flour, defatted pistachio flours, and pistachio oil were performed. Sample was placed on the sample holder of an attenuated total reflectance Fourier Transform Infrared Spectroscopy (ATR-FTIR) Thermo Nicolet iS10 spectrometer (Thermo Scientific, MA, USA). Spectra were registered in the $4000-500 \mathrm{~cm}^{-1}$ range by coadding 128 scans with $4 \mathrm{~cm}^{-1}$ spectral resolution, using OMNIC software (version 8.3, Thermo Scientific, MA, USA). Duplicate spectra were collected from each sample.

The assignation of the bands to a specific functional group vibration mode was made by comparison with spectral data of literature as well as with reference compound spectra included in the software spectral library. Inverted second derivative spectra were used to estimate the number and position of individual elements composing Amide I band $\left(1580-1710 \mathrm{~cm}^{-1}\right)$. This information was taken into account to fit Amide I bands in protein spectra with Gaussian-Lorennz band profiles, using PeakFit software (version 4.12 for Windows, SPSS Inc., Chicago, IL, USA). The assignment of protein secondary structures to the principal Amide I frequencies was performed as previously described in literature (Gerbino et al. 2011).

Differential scanning calorimetry (DSC) Aqueous suspensions of pistachio flour $(\mathrm{P})$ or defatted pistachio flour (DP) at $20 \% \mathrm{w} / \mathrm{w}$ and $40 \% \mathrm{w} / \mathrm{w}$ were prepared $24 \mathrm{~h}$ before the assay. A portion (10 $\mathrm{mg}$ ) of the suspension was placed in aluminum capsules that were hermetically sealed and subjected to one heating cycle from 10 to $140{ }^{\circ} \mathrm{C}$ at a rate of $10^{\circ} \mathrm{C} / \mathrm{min}$ in a calorimeter Q100 DSC (TA Instruments, USA). Protein denaturation process was characterized by onset $\left(\mathrm{T}_{0}\right)$, peak $\left(\mathrm{T}_{\mathrm{p}}\right)$, and final $\left(\mathrm{T}_{\mathrm{f}}\right)$ temperatures and the enthalpy change $(\Delta H)$ was determined between $T_{0}$ and $T_{f}$. Assays were performed by duplicate.

\section{Statistical analysis}

Values were expressed as mean \pm standard deviation of replicates. Statistical analysis was performed with Statgraphic Centurion XV for Windows 15.2.06 Software using with level of significance defined at $p<0.05$.

\section{Results and discussion}

Pistachio flour obtained as a by-product of the pistachio oil industry (Aceites del Desierto S.R.L., Argentina) presented $7.61 \pm 0.05 \%$ of moisture, $33.2 \pm 0.3 \%$ of protein, $30.6 \pm 0.3 \%$ of lipids, and $3.5 \pm 0.2 \%$ of total ash. In addition, pistachio flour presented $29.3 \%$ of carbohydrates, of which $13.6 \pm 0.5 \%$ is total dietary fiber, an important component for human health. The rest of the available carbohydrates found was sucrose $(8.3 \pm 0.5 \%)$, starch $(5.9 \pm 0.7 \%), \quad$ glucose $\quad(0.9 \pm 0.3 \%), \quad$ and fructose $(0.6 \pm 0.2 \%)$. Therefore, pistachios are considered a nutritionally dense nut after oil extraction due to $100 \mathrm{~g}$ of this flour provide $471 \mathrm{kcal}$, being this energy contributed by proteins in $28 \%$, by lipids in a $58.8 \%$ and $62.8 \%$ of calories provided by carbohydrates. Further, this by-product covered half of the recommended intake of dietary fiber proposed by World Health Organization ( $>25 \mathrm{~g}$ per day of total dietary fiber) (World Health Organization 2003).

Water availability of the by-product was $0.711 \pm 0.003$; hence the development of pathogenic microorganisms is 
not favored while lipid oxidation could occur in this ingredient.

\section{Antioxidant activity and nutritional contribution of pistachio flour}

The total content of phenols of pistachio flour was $7.1 \pm 0.8 \mathrm{mg} / \mathrm{g}$ and the antioxidant activity value obtained by FRAP was $8139 \mu \mathrm{g}$ trolox/g and the amount of flour required to obtain a $50 \%$ radical inhibition $\left(\mathrm{EC}_{50}\right)$ was $41.8 \mathrm{mg}$ pistachio flour $/ \mathrm{mL}$. Pistachio nut are a rich source of phenolic compounds like anthocyanins, flavan-3-ols, proanthocyanidins, flavonols, isoflavons, flavanones, stilbenes and phenolics acids with high antioxidant activity; these compounds have protective effects in the prevention of inflammatory activities, cardiovascular diseases and cancer (Tomaino et al. 2010). Taghizadeh et al. (2018) studied the levels and antioxidant activities of some secondary metabolites isolated from five pistachio (Pistacia vera L.) cultivars collected from four different geographical regions of Iran; these authors found lower values $(<12.59 \mu \mathrm{g} / \mathrm{mL})$ of $\mathrm{EC}_{50}$ in all samples compared to our data, probably because lipids also contribute to the antioxidant activity.

The total content of minerals (ash) for the defatted pistachio flour of this work was lower $(3.5 \pm 0.2 \%)$ in comparison to that obtained by Rabadán et al. (2018) for different pistachio samples; they reported a mineral concentration ranging between 4.95 and $4.21 \%$. The mineral contribution of the pistachio by-product and the recommended nutrient intake (RNI) from World Health Organization is shown in Table 1 . Potassium $(\mathrm{K})$ is the principal mineral present in pistachio flours covering $25 \%$ of the
RNI. This mineral is widely available in different kind of foods (potatoes, meat, cereals and milk), and a deficiency of this mineral is uncommon (Lanham-New et al. 2012). Regarding sodium $(\mathrm{Na})$, the level of this mineral in pistachio by-product flour is low and covers $3 \%$ of RNI (Table 1). Therefore, this flour present a good $\mathrm{Na}-\mathrm{K}$ balance that could prevent the incidence of diseases (arterial hypertension, cardiovascular accident) commonly observed in persons that consume high amounts of sodium (Farquhar et al. 2015). Both minerals, $\mathrm{Na}$ and $\mathrm{K}$, are widely distributed in the organisms and are linked in their functions; also their proportions directly influence several vital functions such as the maintenance of the ionic medium for enzymatic reactions, regulation of the membrane potential and the intervention in the conduction of the nerve impulse and muscle contraction (Pita Martin de Portela 2003). Moreover, a portion of $100 \mathrm{~g}$ of pistachio flour contribute with $16 \%$ of the RNI for calcium (Ca) and also with $87 \%$ for the RNI of phosphorous $(\mathrm{P})$. Calcium is in low proportion in foods, being dairy products those that contain the highest amount of this mineral. In Argentina, the requirements of this mineral in a high proportion of the population, are not covered; due to bad eating habits (National Survey on Nutrition and Health 2007). With a low calcium intake, the risk of osteoporotic fractures increases in adult people (more than 50 years old); this deficiency can be correct with an additional intake of calcium plus vitamin D supplement (Weaver et al. 2016). Phosphorous is important because jointly with calcium are in bones in the form of hydroxyapatite in a ratio $\mathrm{Ca}: \mathrm{P}=2: 1$. In addition, $\mathrm{P}$ is an important component of membrane lipids and genetic materials (DNA, RNA) contributing to formation of ATP
Table 1 Mineral content of pistachio flour

\begin{tabular}{lll}
\hline Minerals & Minerals & Recommended nutrient intakes (RNI) \\
\hline Potassium $(\mathrm{K})(\mathrm{mg} \%)$ & $1178 \pm 2$ & $4700 \mathrm{mg}$ \\
Sodium $(\mathrm{Na})(\mathrm{mg} \%)$ & $65 \pm 10$ & $2400 \mathrm{mg}$ \\
Phosphorous $(\mathrm{P})(\mathrm{mg} \%)$ & $613 \pm 5$ & $700 \mathrm{mg}$ \\
Calcium $(\mathrm{Ca})(\mathrm{mg} \%)$ & $158 \pm 14$ & $1000 \mathrm{mg}$ \\
Magnesium $(\mathrm{Mg})(\mathrm{mg} \%)$ & $143 \pm 4$ & $260 \mathrm{mg}$ \\
Iron $(\mathrm{Fe})(\mathrm{mg} \%)$ & $7 \pm 1$ & $14 \mathrm{mg}$ \\
Zinc $(\mathrm{Zn})(\mathrm{mg} \%)$ & $3.0 \pm 0.1$ & $7 \mathrm{mg}$ \\
Copper $(\mathrm{Cu})(\mu \mathrm{g} \%)$ & $2800 \pm 900$ & $900 \mu \mathrm{g}$ \\
Manganese $(\mathrm{Mn})(\mathrm{mg} \%)$ & $1.08 \pm 0.05$ & $2.3 \mathrm{mg}$ \\
Molybdenum $(\mathrm{Mo})(\mu \mathrm{g})$ & $<\mathrm{dl}$ & $45 \mu \mathrm{g}$ \\
Selenium $(\mathrm{Se})(\mu \mathrm{g})$ & $<\mathrm{dl}$ & $34 \mu \mathrm{g}$
\end{tabular}

Value of detection limit from: Mo $(202.030 \mathrm{~nm})$ was $0.021 \mathrm{mg} / \mathrm{L}$ $d l$ detection limit

${ }^{\mathrm{a}}$ Recommended Nutrient Intake (RNI) from World Health Organization and Food and Agriculture Organization of the United Nations WHO/FAO, for males and females, aged between 19 and 65 years (WHO and FAO 2004) 
and phosphoric intermediate compounds in metabolism of nutrients (Pita Martin de Portela 2003).

Pistachio flour contribute with $55 \%$ of the RNI of magnesium $(\mathrm{Mg})$, however deficiencies in this mineral are not evident due to human body present a mechanism for ensure its bioavailability (Nielsen 2018).

In relation to macro elements, Rabadán et al. (2018) obtained similar values of $\mathrm{P}, \mathrm{Mg}, \mathrm{Ca}$ and $\mathrm{K}$ for the defatted by-product flour from pistachio Kerman cultivar.

Iron $(\mathrm{Fe})$ is an essential mineral for the energetic and oxidative metabolism. A deficiency of $\mathrm{Fe}$ is associated to a low intake or bioavailability of this mineral from the diet; consuming adequate amounts of iron prevents iron-deficiency anemia. Pistachio flour covers the $50 \%$ of the RNI of iron. This flour also covers about $43 \%$ and $47 \%$ of the RNI for zinc $(\mathrm{Zn})$ and manganese $(\mathrm{Mn})$, respectively (Table 1). Zinc is an essential mineral for several enzymes activities and it is also related to oxidative protection and synthesis of proteins, among other functions. Rabadán et al. (2018) obtained for the defatted by-product flour from pistachio Kerman cultivar values for Fe (4 mg\%) and $\mathrm{Mn}$ $(2.32 \mathrm{mg} \%)$ lower and higher, respectively, respect to those informed in the present work (Table 1).

In addition, $\mathrm{Zn}$ is important for fertility and male genital health, also favors formation of DNA and the optimum function of immunological system (Livingstone 2015). Copper $(\mathrm{Cu})$ content in this by-product flour is three times greater than the amount intake established by WHO/FAO (WHO and FAO 2004). This mineral act as cofactor in superoxide dismutase enzyme present in aerobic cells (WHO and FAO 2004), and jointly with zinc are important minerals for brain neurotransmitters; copper also enhance calcium and phosphorus fixation.

In summary, the consumption of $100 \mathrm{~g}$ of pistachio flour contributes to the half of the daily recommended intake of essential minerals, converting this by-product in a good ingredient complement of cereal flours. Fabani et al. (2013) found that the mineral content of pistachio seeds was lower than that obtained in this work, and also observed that this content increased with the age of the tree $(5,9$, and 11 years).

Pistachio by-product presented $30 \%$ of lipids, important components for human nutrition due to one third of the energy supported by diet is contributed by this faction. Table 2 shows the fatty acid profile of the pistachio byproduct and results found by other authors were included for comparison. The major proportions for oleic, linoleic and palmitic acids and a five times higher than proportion of unsaturated with respect to saturated fatty acids were identified in our by-product (Table 2). The proportion of fatty acids (saturated, mono and polyunsaturated) present in lipids from the by-product pistachio flour was similar to those obtained in colza and sesame oils (Guillén and Cabo
1999). Different authors studied the fatty acid profile of pistachios cultivated in Turkey (Gecgel et al. 2011) and Iran (Mahmoodabadi et al. 2012; Rabadán et al. (2018). These authors found that the percentage of the linoleic and a-linolenic acids was lower than those reported in this work, with the exception of stearic and oleic acids that were higher than those observed in this by-product (Table 2).

Besides the high amount of protein (33.2\%) of this byproduct, the knowledge of the amino acids profile result interesting from the nutritional point of view. Pistachio proteins presented $21.29 \%$ of basic amino acids (Lys, Hys and Arg), 29.69\% of acidic amino acids (Asp and Glu), $22.09 \%$ of polar and hydrophilic amino acids (Thr, Cys, Tyr, Ser and Gly) and $26.93 \%$ of non-polar hydrophobic amino acids (Table 3). Conversion factor from nitrogen-toprotein was 6.25 and was calculated from the amount of amino acids present in pistachio proteins. These polymers present $46.98 \mathrm{~g}$ of essential amino acids per $100 \mathrm{~g}$ protein, that are Lys, His, Val, Ile, Leu, Thr, Met, Cys, Tyr, Phe and Trp. These amino acids must be incorporated through the diet. Comparing to FAO reference protein (Joint WHO 2007), proteins from pistachio nut provided 1.5 times of Lys, Val, Ile, and Leu and 1.7 times more of Hys and Thr (Table 3). Although pistachio proteins have a high contribution of cysteine (Cys), these proteins resulted deficient in Met (chemical score $=55.6 \%$ ). Therefore, pistachio byproduct is a promising ingredient to supplement proteins from Lys-deficient cereals like wheat and rice, but is not adequate to complement legumes. Some authors reported similar values in contents of some amino acid of pistachio from California (Clarke et al. 1976), nevertheless these authors obtained higher amounts of methionine and lower of aromatic amino acids than those observed for the pistachio by-product.

\section{Structural and thermal properties of pistachio by- product}

The ATR-FTIR spectra in the $4000-800 \mathrm{~cm}^{-1}$ region shows bands corresponding to stretching and deformation of the main functional groups of the macro components (Fig. 1a). The major bonds of biological interest are placed in the regions of 3600-2800 and 1800-800 $\mathrm{cm}^{-1}$ (BarrazaGarza et al. 2013). The significant bands presented in different pistachio samples are shown in Fig. 1a, and the assignments of the functional groups to each band are described in Table 4. The following regions were analyzed:

- $3700-3100 \mathrm{~cm}^{-1}$ A wide band at $3267 \mathrm{~cm}^{-1}$ in pistachio and defatted pistachio flour was observed, attributed to $\mathrm{OH}$-stretching vibrations of hydroxyl groups of water and starch (Monroy et al. 2018). 
Table 2 Fatty acid contents of lipids from pistachio flour

\begin{tabular}{|c|c|c|c|c|c|}
\hline \multicolumn{2}{|c|}{ Fatty acid methyl esters (FAME) } & \multirow[t]{2}{*}{$\operatorname{FAME}(\%)^{\mathrm{a}}$} & \multicolumn{3}{|l|}{ FAME $(\%)^{\mathrm{b}}$} \\
\hline & & & Gecgel et al. (2011) & Mahmoodabadi et al. (2012) & Rabadán et al. (2018) \\
\hline Palmitic acid & $\mathrm{C} 16: 0$ & $11.2 \pm 0.1$ & 7.75 & 8.90 & 10.84 \\
\hline Palmitoleic acid & $\mathrm{C} 16: 1-\omega 7$ & $1.8 \pm 0.9$ & 0.62 & 0.83 & 1.13 \\
\hline Stearic acid & $\mathrm{C} 18: 0$ & $0.7 \pm 0.3$ & 1.95 & 1.29 & 1.15 \\
\hline Oleic acid & C18:1- $\omega 9$ & $52.3 \pm 3.7$ & 67.76 & 62.56 & 59.21 \\
\hline Linoleic acid & $\mathrm{C} 18: 2-\omega 6$ & $31.0 \pm 1.7$ & 20.73 & 23.49 & 29.44 \\
\hline$\alpha$-Linolenic acid & $\mathrm{C} 18: 3-\omega 3$ & $0.7 \pm 0.1$ & 0.39 & 0.47 & 0.44 \\
\hline Gadoleic acid & $\mathrm{C} 20: 1$ & nd & 0.74 & 0.34 & 0.33 \\
\hline Arachidic acid & $\mathrm{C} 20: 0$ & nd & nd & nd & 0.13 \\
\hline Behenic acid & $\mathrm{C} 22: 1$ & nd & nd & nd & 0.09 \\
\hline \multicolumn{2}{|c|}{ Total saturated fatty acid } & $11.9 \pm 0.3$ & 9.7 & 10.19 & 12.12 \\
\hline \multicolumn{2}{|c|}{ Total unsaturated fatty acid } & $54 \pm 3$ & 69.12 & 63.73 & 60.76 \\
\hline \multicolumn{2}{|c|}{ Total polyunsaturated fatty acid } & $32 \pm 2$ & 21.12 & 23.96 & 29.88 \\
\hline
\end{tabular}

nd Not detected

${ }^{a}$ Data are expressed as percentage of total fatty acid methyl ester.

${ }^{\mathbf{b}}$ FAME composition found for Pistacia vera L. cv Kerman (Mahmoodabadi et al. 2012; Rabadán et al 2018), for Pistacia vera L. Anacitlak variety (Gecgel et al. 2011)

Table 3 Amino acid composition from pistachio flour

\begin{tabular}{lcc}
\hline Amino acid & Amino acid (g/100 g of protein) & Joint WHO (2007) \\
\hline Lysine (Lys) & $7.03 \pm 0.06$ & 4.5 \\
Histidine (His) & $2.62 \pm 0.02$ & 1.5 \\
Valine (Val) & $5.74 \pm 0.14$ & 3.9 \\
Isoluecine (Ile) & $4.56 \pm 0.05$ & 3.0 \\
Leucine (Leu) & $9.18 \pm 0.14$ & 5.9 \\
Threonine (Thr) & $4.09 \pm 0.02$ & 2.3 \\
Methionine (Met) & $0.89 \pm 0.05$ & 1.6 \\
Cysteine (Cys) & $1.69 \pm 0.14$ & 0.6 \\
Met + Cys & $2.58 \pm 0.14$ & 2.2 \\
Tyrosine (Tyr) & $3.54 \pm 0.01$ & \\
Phenylalanine (Phe) & $6.99 \pm 0.01$ & 3.8 \\
Tyr + Phe & $10.53 \pm 0.01$ & 0.6 \\
Tryptophan (Trp) & $0.65 \pm 0.01$ & \\
Serine (Ser) & $7.32 \pm 0.12$ & \\
Aspartate (Asp) + glutamate (Glu) & $29.69 \pm 0.15$ & \\
Proline (Pro) & $7.31 \pm 0.40$ & \\
Glycine (Gly) & $5.45 \pm 0.04$ & \\
Alanine (Ala) & $5.37 \pm 0.03$ & \\
Arginine (Arg) & $11.64 \pm 0.17$ & \\
& $113.76 \pm 1.56$ & \\
\hline Amino acid & &
\end{tabular}

${ }^{a}$ Amino acid requirements in human nutrition-Joint WHO (2007)
- $3100-2800 \mathrm{~cm}^{-1}$ Three bands were observed in pistachio flour and oil, the band at $3007 \mathrm{~cm}^{-1}$ was assigned to $c i s$ double bound stretching vibration of olefin groups of unsaturated fatty acids. Besides, the two bands observed at 2922 and $2853 \mathrm{~cm}^{-1}$ correspond to the asymmetric and symmetric stretching vibrations of aliphatic $\mathrm{CH}_{2}$ functional groups, respectively. Furthermore, the band at $2922 \mathrm{~cm}^{-1}$ is associated with the 

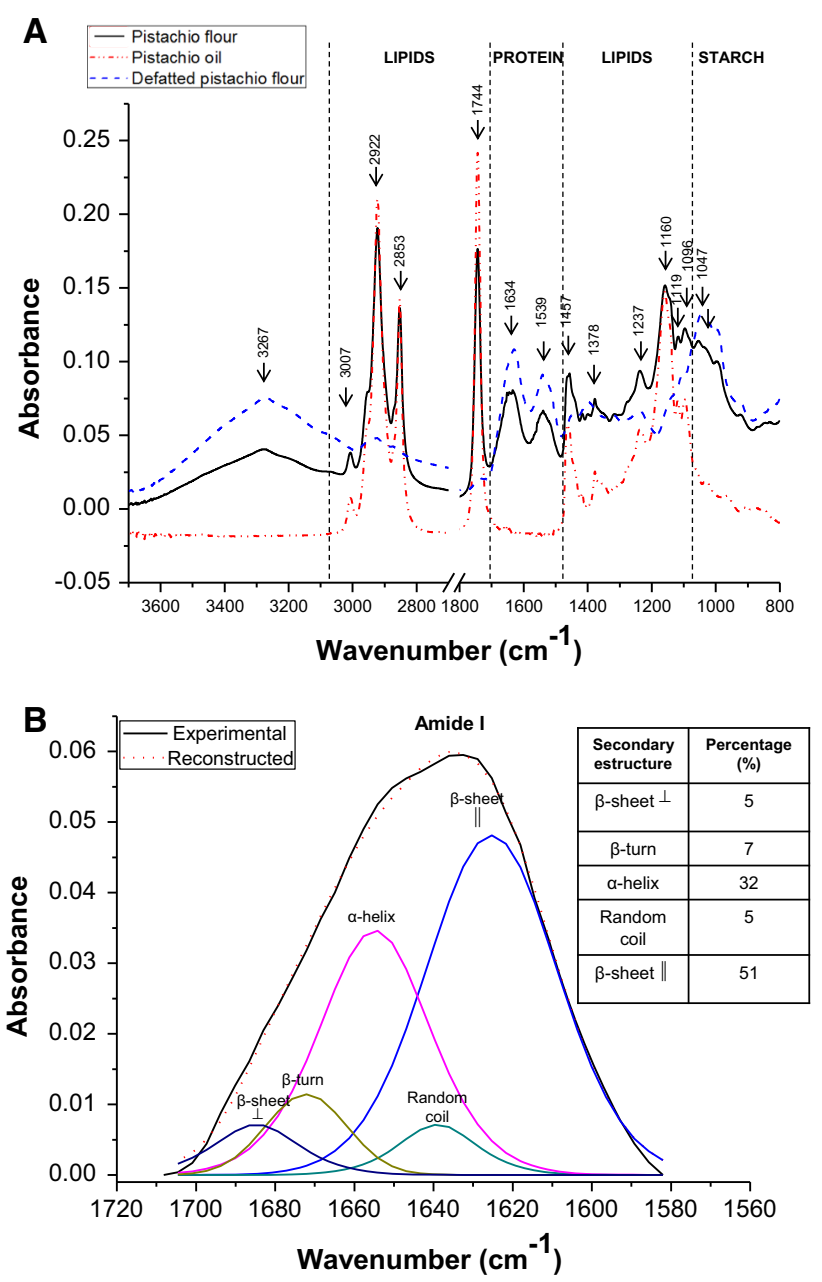

Fig. 1 a ATR-FTIR whole spectra of the pistachio flour (black full line), pistachio oil (red dash dot dot line), and defatted pistachio flour (blue dashed line). b Deconvolved amide I band of defatted pistachio flour (color figure online)

saturated fatty acids fraction present in pistachio lipids (Guillén and Cabo 2000).

- $1800-1700 \mathrm{~cm}^{-1}$ The band at $1744 \mathrm{~cm}^{-1}$ observed for pistachio flour and oil is associated to the $\mathrm{C}=\mathrm{O}$ stretching vibration of the ester carbonyl of the triglyceride.

- $1700-1500 \mathrm{~cm}^{-1}$ The two bands observed for both pistachio flours at 1634 and $1539 \mathrm{~cm}^{-1}$ were previously found by $\mathrm{Ng}$ et al. (2014) in pistachio nuts spectrum, and they assigned these bands to the bending vibration of $\mathrm{N}-\mathrm{H}$ functional group in Amide I and Amide II.

- $1500-1070 \mathrm{~cm}^{-1}$ Weak bands at 1457 and $1378 \mathrm{~cm}^{-1}$ were distinguished in this region and associated by Guillén and Cabo (1999) to the presence of $\mathrm{CH}$ bending vibrations in $\mathrm{CH}_{2}$ and $\mathrm{CH}_{3}$ groups. Besides, four bands at $1237,1160,1119$, and $1096 \mathrm{~cm}^{-1}$ were observed in samples that contain lipids associated them to the stretching vibration of the $\mathrm{C}-\mathrm{O}$ group in esters.
- $1070-800 \mathrm{~cm}^{-1}$ A band at $1047 \mathrm{~cm}^{-1}$ appeared in both flours and it can be attributed to the stretching vibration of $\mathrm{C}-\mathrm{O}$ functional groups characteristic of carbohydrates being more intense in the defatted flour that present high proportion of starch (García et al. 2013; Monroy et al. 2018).

As intensity of FTIR bands of by-product pistachio flour are straightforward related with chemical composition, changes in intensity of bands could be used as a rapid evaluation of the effectiveness of different technological process, like lipid extraction. In addition, due to the high proportion of proteins present in the by-product, changes in structure and thermal properties of proteins can bring valuable information for the use of this ingredient in food industry.

Different types of secondary structures of proteins were analyzed through the de-convolution of the Amide I band of the ATR-FTIR spectra (Fig. 1b). The five structures characterized were localized at approximately $1620 \mathrm{~cm}^{-1}$ (parallel $\beta$-sheet), $1640 \mathrm{~cm}^{-1}$ (random coil), $1665 \mathrm{~cm}^{-1}$ ( $\alpha$-helix), $1678 \mathrm{~cm}^{-1}$ ( $\beta$-turn) and $1685 \mathrm{~cm}^{-1}$ (antiparallel $\beta$-sheet). Pistachio proteins presented $56 \% \beta$-sheet (parallel and anti-parallel), 32\% $\alpha$-helix, $7 \% \beta$-turns and $5 \%$ random coil. Dogan et al. (2007) found in other nut like hazelnut a similar tendency, with a greater proportion of $\beta$-sheet than $\alpha$-helix. No studies were found at present on pistachio proteins.

One of the food applications of this by-product could be in baked goods; thus, thermal behavior of pistachio flour was studied by DSC analysis. Thermograms of aqueous suspensions of by-product (P) and defatted (DP) pistachio flours, at $20 \%$ and $40 \%$ (w/v) are shown in Fig. 2. Suspension 20\% w/v (DP20) presented an endotherm with a peak temperature $(\mathrm{Tp})$ at $103{ }^{\circ} \mathrm{C}$; a similar behavior was obtained for P20. A comparable tendency was observed for $40 \%$ suspensions, although Tp were displaced to higher temperatures, due to the lower amount of water present in the dispersion. In addition, the lower Tp obtained for the pistachio by-product sample $(\mathrm{P})$ suggest that the residual lipid fraction confers to the flour a less thermal stability. The endotherms observed can be attributed to protein denaturation because starch gelatinizes around $60{ }^{\circ} \mathrm{C}$, and no endotherm was observed at that temperature (data not shown). The assignment of the endotherm to proteins was evidenced by the values of denaturation enthalpy, because slightly higher values of this parameter were obtained in the absence of the lipid fraction (DP), i.e. in samples with high proportion of proteins. 
Table 4 FTIR functional group composition

\begin{tabular}{lll}
\hline Wavenumber $\left(\mathrm{cm}^{-1}\right)$ & Functional group & Flour component \\
\hline 3267 & O-H stretching & Water, starch \\
3007 & cis double bound stretching vibration & Lipids \\
2922 & Asymmetric stretching vibration of aliphatic $\mathrm{CH}_{2}$ & Protein \\
2853 & Symmetric stretching vibration of aliphatic $\mathrm{CH}_{2}$ & Lipids \\
1744 & $\mathrm{C}=\mathrm{O}$ stretching of ester carbonyl of the triglycerides \\
1634 & N-H bending (Amide I) & \\
1539 & N-H bending (Amide II) & \\
1457 & Asymmetric bending vibration of aliphatic $\mathrm{CH}_{2}$ and $\mathrm{CH}_{3}$ groups & \\
1378 & Symmetric bending vibration of $\mathrm{CH}_{2}$ group \\
1237 & Stretching vibration of $\mathrm{C}-\mathrm{O}$ group & Carbohydrates \\
1160 & Bending vibration of $\mathrm{CH}$ group \\
1096 & Stretching vibration of $\mathrm{C}=\mathrm{O}$ group \\
\hline
\end{tabular}

${ }^{\mathrm{a}}$ Guillén and Cabo (2000)

${ }^{\text {b }} \mathrm{Ng}$ et al. (2014)

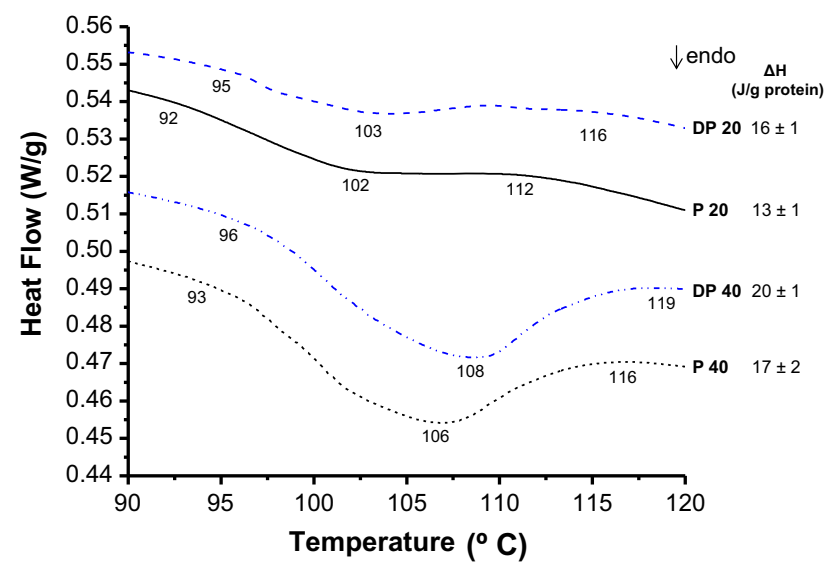

Fig. 2 DSC thermograms of suspension of pistachio flour: $D P$ defatted pistachio flour, $P$ pistachio flour. Suspension at 20\% (DP20, P20) and 40\% (DP40, P40) were prepared in distilled water. Values of temperatures and enthalpy of protein denaturation $(\Delta \mathrm{H})$ are shown

\section{Conclusion}

The pistachio by-product obtained from oil Industry present high amount of lipids, proteins and total dietary fiber. Fiber is in a proportion higher than $6 \%$, the minimum required for considering this ingredient as a "good source" of dietary fiber content claim (according regulatory law in the United States and the European Union). On the other hand, the high antioxidant activity of pistachio flour can protect unsaturated fatty acids present in lipids against oxidation. In addition, this flour presents higher amounts of minerals than the whole nut. Proteins are of high biological value, providing about half of the essential amino acids amount. Although these proteins were limited in methionine, they contribute with the half proportion of the lysine recommended by FAO. All these characteristics convert this by-product in a good ingredient for complementing cereals and for applications in functional foods.

Acknowledgements This work was supported by the Argentinean Agency for the Scientific and Technological Promotion (ANPCyT; Projects PICT/2013/0007, PICT/2014/1531, PICT/2016/3047). Argentinean Research Council (CONICET), and the Universidad Nacional de La Plata. We want also to thank CNR (Italy) through the bilateral cooperation project between CIDCA, La Plata-CONICET (Argentina), ISA, Avellino-CNR (Italy). We also want to thank Domingo Montaño (Aceites del Desierto S.R.L.) for the provision of the pistachio by-product sample.

\section{Compliance with ethical standards}

Conflict of interest The authors declare that they have no conflict of interest.

\section{References}

AACC (2000) Approved methods of the American association of cereal chemists, 10th edn. The Association, St. Paul

Barraza-Garza G, de la Rosa LA, Martínez-Martínez A, CastilloMichel H, Cotte M, Alvarez-Parrilla E (2013) La microespectroscopía de infrarrojo con transformada de Fourier (FTIRM) en el estudio de sistemas biológicos. Rev Latinoam Quím $41: 125-148$

Barth A (2007) Infrared spectroscopy of proteins. Biochim Biophys Acta BBA-Bioenergy 1767:1073-1101 
Carbas B, Salinas MV, Serrano C, Passarinho JA, Puppo MC, Ricardo CP, Brites C (2019) Chemical composition and antioxidant activity of commercial flours from Ceratoniasiliqua and Prosopis spp. J Food Meas Charact 13:305-311

Cian RE, Garzón AG, Ancona DB, Guerrero LC, Drago SR (2015) Hydrolyzates from Pyropia columbina seaweed have antiplatelet aggregation, antioxidant and ACE I inhibitory peptides which maintain bioactivity after simulated gastrointestinal digestion. LWT-Food Sci Technol 64:881-888

Clarke JA, Brar GS, Procopiou J (1976) Fatty acid, carbohydrate and amino acid composition of pistachio (Pistacia vera) kernels. Qual Plant 25:219-225

Dogan A, Siyakus G, Severcan F (2007) FTIR spectroscopic characterization of irradiated hazelnut (Corylus avellana L.). Food Chem 100:1106-1114

Ehsanpour AA, Shojaie B, Rostami F (2010) Characterization of seed storage protein patterns of four Iranian pistachios using SDSPAGE. Nat Sci 2:737-740

Eliasson A-C (2006) Carbohydrates in food, 2nd edn. CRC Press, New York, USA

Fabani MP, Luna L, Baroni MV, Monferran MV, Ighani M, Tapia A, Wunderlin DA, Feresin GE (2013) Pistachio (Pistacia vera var Kerman) from Argentinean cultivars. A natural product with potential to improve human health. J Funct Foods 5:1347-1356

Farquhar WB, Edwards DG, Jurkovitz CT, Weintraub WS (2015) Dietary sodium and health: more than just blood pressure. J Am Coll Cardiol 65:1042-1050

García AV, Beltrán Sanahuja A, Garrigós SelvaDel MC (2013) Characterization and classification of almond cultivars by using spectroscopic and thermal techniques. J Food Sci 78:C138-C144

Gecgel U, Gumus T, Tasan M, Daglioglu O, Arici M (2011) Determination of fatty acid composition of $\gamma$-irradiated hazelnuts, walnuts, almonds, and pistachios. Radiat Phys Chem 80:578-581

Gerbino E, Mobili P, Tymczyszyn E, Fausto R, Gómez-Zavaglia A (2011) FTIR spectroscopy structural analysis of the interaction between Lactobacillus kefir S-layers and metal ions. J Mol Struct 987:186-192

Guardianelli LM, Salinas MV, Puppo MC (2019) Chemical and thermal properties of flours from germinated amaranth seeds. J Food Meas Charact 13(2):1078-1088

Guillén MD, Cabo N (2000) Some of the most significant changes in the Fourier transform infrared spectra of edible oils under oxidative conditions. J Sci Food Agric 80:2028-2036

Guillén MD, Cabo N (1999) Usefulness of the frequency data of the Fourier transform infrared spectra to evaluate the degree of oxidation of edible oils. J Agric Food Chem 47:709-719

Joint FAO (2010) Fats and fatty acids in human nutrition. Report of an expert consultation, 10-14 November 2008, Geneva

Joint WHO (2007) Protein and amino acid requirements in human nutrition. World Health Organ Tech Rep Ser 935:1

Kedare SB, Singh R (2011) Genesis and development of DPPH method of antioxidant assay. J Food Sci Technol 48:412-422

Konieczny P, Tomaszewska-Gras J, Andrzejewski W, Mikołajczak B, Urbańska M, Mazurkiewicz J, Stangierski J (2016) DSC and electrophoretic studies on protein denaturation of Anodonta woodiana (Lea, 1834). J Therm Anal Calorim 126:69-75

Lanham-New SA, Lambert H, Frassetto L (2012) Potassium Adv Nutr Bethesda Md 3:820-821

Livingstone C (2015) Zinc: physiology, deficiency, and parenteral nutrition. Nutr Clin Pract 30:371-382

Mahmoodabadi SK, Panahi B, Agharehimi J, Talaie A (2012) Determination of fatty acids, protein and amino acids in fruits of three pistachio (Pistacia vera L.) cultivars in Kerman Province. Iran Plant Ecophysiol 4:125-128

Monroy Y, Rivero S, García MA (2018) Microstructural and technofunctional properties of cassava starch modified by ultrasound. Ultrason Sonochem 42:795-804

National Survey on Nutrition and Health (2007) National Survey on Nutrition and Health, Argentina

Ng S, Lasekan O, Muhammad K, Sulaiman R, Hussain N (2014) Effect of roasting conditions on color development and Fourier transform infrared spectroscopy (FTIR-ATR) analysis of Malaysian-grown tropical almond nuts (Terminalia catappa $\mathrm{L}$.). Chem Cent J 8:55

Nielsen FH (2018) Magnesium deficiency and increased inflammation: current perspectives. J Inflamm Res 11:25-34

Pardo-Giménez A, Catalán L, Carrasco J et al (2016) Effect of supplementing crop substrate with defatted pistachio meal on Agaricus bisporus and Pleurotus ostreatus production. J Sci Food Agric 96:3838-3845

Pita Martin de Portela ML (2003) Vitaminas y minerales en nutrición, 2nd edn. La Prensa Médica Argentina, Buenos Aires

Rabadán A, Álvarez-Ortí M, Gómez R et al (2018) Characterization of pistachio oils and defatted flours regarding cultivar and geographic origin. J Food Compos Anal 71:56-64

Shokraii EH, Esen A (1988) Composition, solubility and electrophoretic patterns of proteins isolated from Kerman pistachio nuts (Pistacia vera L.). J Agric Food Chem 36:425-429

Singleton VL, Orthofer R, Lamuela-Raventós RM (1999) Analysis of total phenols and other oxidation substrates and antioxidants by means of folin-ciocalteu reagent. Methods Enzymol 299:152-178

Taghizadeh SF, Davarynejad G, Asili J, Nemati SH, Karimi G (2018) Assessment of phenolic profile and antioxidant power of five pistachio (Pistacia vera) cultivars collected from four geographical regions of Iran. Avicenna J Phytomed 8:33

Tananuwong K, Reid DS (2005) DSC study of starch-water interactions during gelatinization and amylose-lipid complex dissociation of corn starches. In: The 3rd conference of starch technology. Bangkok, Thailand, pp 123-128

Tomaino A, Martorana M, Arcoraci T, Monteleone D, Giovinazzo C, Saija A (2010) Antioxidant activity and phenolic profile of pistachio (Pistacia vera L., variety Bronte) seeds and skins. Biochimie 92:1115-1122

USDA (2018) Nuts, pistachio nuts, raw (USDA National Nutrient Database for Standard Reference No. Basic Report 12151), USA

Weaver CM, Alexander DD, Boushey CJ, Dawson-Hughes B, Lappe JM, LeBoff MS, Liu S, Looker AC, Wallace TC, Wang DD (2016) Calcium plus vitamin D supplementation and risk of fractures: an updated meta-analysis from the National Osteoporosis Foundation. Osteoporos Int 27:367-376

WHO, FAO (2004) Vitamin and mineral requirements in human nutrition: report of a Joint FAO/WHO Expert Consultation, Bangkok, Thailand, 21-30 September 1998, 2nd edn. World Health Organization, Geneva

World Health Organization (2003) Diet, nutrition, and the prevention of chronic diseases: report of a joint WHO/FAO expert consultation. World Health Organization, Geneva

Yust MM, Pedroche J, Girón-Calle J, Vioque J, Millán F, Alaiz M (2004) Determination of tryptophan by high-performance liquid chromatography of alkaline hydrolysates with spectrophotometric detection. Food Chem 85(2):317-320

Publisher's Note Springer Nature remains neutral with regard to jurisdictional claims in published maps and institutional affiliations. 